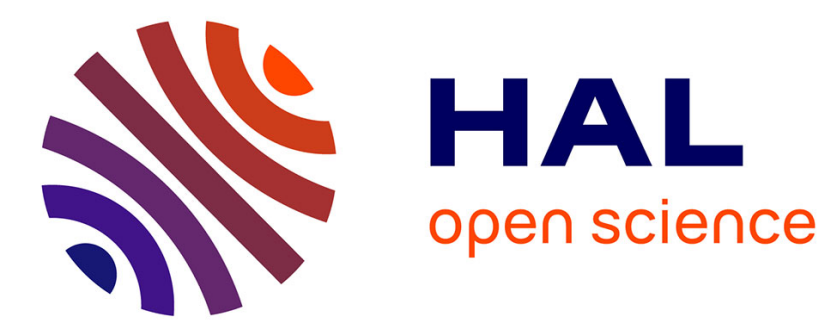

\title{
Integration of the human exposome with the human genome to advance medicine
}

Robert Barouki, Karine Audouze, Xavier Coumoul, Florence Demenais, Dominique Gauguier

\section{- To cite this version:}

Robert Barouki, Karine Audouze, Xavier Coumoul, Florence Demenais, Dominique Gauguier. Integration of the human exposome with the human genome to advance medicine. Biochimie, 2018, 152, pp.155-158. 10.1016/j.biochi.2018.06.023 . hal-02196327

\section{HAL Id: hal-02196327 \\ https://hal.science/hal-02196327}

Submitted on 27 Jul 2019

HAL is a multi-disciplinary open access archive for the deposit and dissemination of scientific research documents, whether they are published or not. The documents may come from teaching and research institutions in France or abroad, or from public or private research centers.
L'archive ouverte pluridisciplinaire HAL, est destinée au dépôt et à la diffusion de documents scientifiques de niveau recherche, publiés ou non, émanant des établissements d'enseignement et de recherche français ou étrangers, des laboratoires publics ou privés. 
archives-ouvertes

\section{Integration of the human exposome with the human genome to advance medicine}

Robert Barouki, Karine Audouze, Xavier Coumoul, Florence Demenais, Dominique Gauguier

\section{- To cite this version:}

Robert Barouki, Karine Audouze, Xavier Coumoul, Florence Demenais, Dominique Gauguier. Integration of the human exposome with the human genome to advance medicine. Biochimie, 2018, 152, pp.155-158. 10.1016/j.biochi.2018.06.023 . hal-02196327

\section{HAL Id: hal-02196327 \\ https://hal.archives-ouvertes.fr/hal-02196327}

Submitted on 27 Jul 2019

HAL is a multi-disciplinary open access archive for the deposit and dissemination of scientific research documents, whether they are published or not. The documents may come from teaching and research institutions in France or abroad, or from public or private research centers.
L'archive ouverte pluridisciplinaire HAL, est destinée au dépôt et à la diffusion de documents scientifiques de niveau recherche, publiés ou non, émanant des établissements d'enseignement et de recherche français ou étrangers, des laboratoires publics ou privés. 
Mini-review

\title{
Integration of the human exposome with the human genome to advance medicine
}

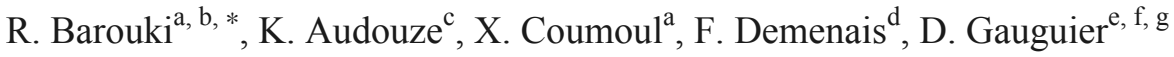 \\ a INSERM UMR-S 1124, Université Paris Descartes, Université Sorbonne Paris Cité, Paris, France \\ b Service de Biochimie Métabolomique et Protéomique, Hôpital Universitaire Necker Enfants Malades, AP-HP, Paris, France \\ ' INSERM UMR-S973, Molécules Thérapeutiques in Silico, Université Paris Diderot, Université Sorbonne Paris Cité, Paris, France \\ d INSERM UMR-S 946, Genetic Variation and Human Diseases Unit, Université Paris Diderot, Université Sorbonne Paris Cité, Paris, France \\ ' INSERM UMR_S1138, Sorbonne Universités, Université Pierre \& Marie Curie, Université Paris Descartes, Sorbonne Paris Cité, Paris, France \\ ${ }^{\mathrm{f}}$ Imperial College London, Section of Biomolecular Medicine, Division of Computational and Systems Medicine, Department of Surgery and Cancer, Faculty of Medicine, Sir \\ Alexander Fleming Building, London, United Kingdom \\ g McGill University and Genome Quebec Innovation Centre, Montréal, Canada
}

\section{A R T I C L E INFO}

Article history:

Received 5 December 2017

Accepted 26 June 2018

Available online $\mathrm{xxx}$

\section{Keywords:}

Exposome

Epigenome

Microbiome

Prevention

Prediction

Metabolome

\begin{abstract}
A B S T R A C T
Identifying precise and predictive biomarkers of health and disease is a critical objective of clinical biochemistry and biomedical research. New concepts and technologies have emerged recently that could support such an objective. The exposome corresponds to the totality of exposure over the lifetime. Research in this field allowed the development of sensors and biological biomarkers using omics technologies that are relevant for predicting the effect of those exposure on human health. Precision medicine has primarily focused on adapting treatments to the genetic profiles of tumors, when in fact, it had originally a wider scope including the use of robust biomarkers for disease prevention. Large-scale genetic studies have also contributed to highlight gene environment interactions, and were extended more recently to epigenetics. In line with the systems medicine approach, we propose to integrate the genome and exposome data in what we present as the exposome-genome paradigm. Such an integrated view will help strengthen approaches to identify relevant predictive markers that can support precise prevention actions both at the population and at the individual levels.
\end{abstract}

(C) 2018 .

\section{Introduction}

A primary objective of clinical biochemistry and biomedical research is to develop tools to better understand and predict human health, response to therapy or to behavioral recommendations and to support prevention. During the last decades, non-communicable diseases including metabolic diseases and obesity, cancers, neurodevelopmental and neurodegenerative disorders, allergies and autoimmune diseases, pulmonary and cardiovascular diseases, have increased considerably [1]. Yet, our ability to predict occurrence and development of those diseases, their associations with other morbidities and their response to treatment remains limited. Risk factors for non-communicable diseases include a complex combination of genetic factors and a variety of environmental stressors [2]. While characterizing such interactions is informative at the population level from a public health perspective, it would be extremely useful to use such knowledge at the individual level. New innovative and relevant concepts and methodologies have been established recently, which may lead to a major leap forward in the assessment and prediction of health and

\footnotetext{
* Corresponding author. INSERM UMR-S 1124, Université Paris Descartes, Université Sorbonne Paris Cité, Paris, France.

Email address: robert.barouki@parisdescartes.fr (R. Barouki)
}

therapies. After briefly summarizing those concepts, we will discuss an approach aiming at integrating those developments i.e. genetics and environmental factors to the benefit of the patients.

\section{The exposome concept}

This innovative concept was developed by Chris Wild in 2005 [3] and aims at integrating all exposures from conception to death. This holistic concept provides a framework for studying the response of the human body, or any other organism, to combined and cumulative exposures. Since then, it has gained momentum, and several EU and international projects are now focusing on characterizing the exposome in different conditions [4]. The concept is quite ambitious since exposure refers basically to anything that is not genetic, i.e. exposure to chemical and physical stressors, biologicals, psychological and social stress, as well as cumulative exposures. The temporal dimension is critical since early life exposures can influence health and well-being later in life as stated by the DOHaD (Developmental Origins of Health and Disease) concept. Exposome research is essentially a multidisciplinary and integrated approach that comprises epidemiological (cohorts), computational, analytical, environmental and toxicological studies as well as a social science component. The exposome studies have benefited from methodological developments such as a variety 
of sensors measuring physiological endpoints or environmental stressors [5], biomarker assays including biomonitoring, metabolomics and proteomics, environmental monitoring (air water, soil), traditional questionnaires, patient records as well as novel data integration models in computer settings [6]. It is now possible not only to gather a global assessment of exposure of a population or a community, but also in some cases to estimate individual exposure. This is critical from a medical perspective.

The microbiome is a critical component of the exposome, at the interface between the environment and various sites of the host organism (skin, gut, airway, ...). The trillions of symbionts, commensals and pathogens that populate the human microbiota represent highly variable bacterial ecosystems across body sites that may adapt to environmental changes. It contributes to multiple essential functions for the host in health and disease, including the metabolism of nutrients into digestible molecules and the maturation of the immune system. Pathological conditions, changes in lifestyles (e.g. diet) and medications can result in profound alterations in the architecture of the microbiome [7], which can in turn modify the regulation of the expression of the host genome. Qualitative and quantitative analyses of products of bacterial metabolism through metabolomic profiling of human biofluids and organ extracts provide functional information on the activity of the microbiome, and opportunities to identify microbial metabolites associated with disease conditions through metabolome-wide association studies (MWAS). This concept is illustrated by the identification of microbial-mammalian co-metabolites (eg. hippurate, methylamines, short chain fatty acids) associated with cardiometabolic diseases [8-10], colitis [11] and allergic inflammation [12], and underlying metabolome-microbiome crosstalk at the crossroads between disease risk alleles and environmental exposure affecting diseases.

\section{Precision medicine}

The concept is much in line with what clinical biochemistry should aim at, i.e. to develop medical tools to predict patient specific features in order to better assess health and therapy. Several large and ambitious programs have been initiated world-wide such as the Precision Medicine Initiative in the US (https://allofus.nih.gov) and the Genomic Medicine 2025 in France (https:/www.aviesan.fr/aviesan/ accueil/toute-1-actualite/plan-france-medecine-genomique-2025). Precision medicine encompasses a number of applications but it has been most widely used and popularized in cancer therapy using tumor genetic tests as a basis for therapeutic orientations. In that sense, it is related to pharmacogenomics, which help at identifying new drug targets, biomarkers and at providing diagnostic evidence, based on a person's genetic makeup. Yet, the ambition of precision medicine should be much wider but, in practice, it relies primarily on genomic profile. It is reasonable to suggest that other features characterizing an individual and its susceptibility can be used to tailor an adapted therapy or to predict health and well-being $[13,14]$. As an example, recent studies in cancer research have unraveled the role of the so-called "oncometabolites" and their diagnostic value [15].

\section{GWAS, EWAS, GEWIS}

Several large-scale clinical and epidemiological studies, i.e. Genome-Wide Association Study (GWAS) have attempted to correlate genetic polymorphisms with a trait such as a human disease or a phenotype. This has led to the identification of several genetic variants involved in a variety of human complex diseases and endophenotypes. A similar approach, i.e. Environmental-Wide Association
Study (EWAS) has been used to correlate exposure to an environmental stressor (such as pollutants or nutrients) with a trait benefiting from cross-sectional or large cohort studies [16]. More recently epidemiological studies have attempted to evaluate the interaction between genes and environment (G x E or GEWIS, Genome-Environment-wide Interaction Studies) [17]. Those studies are carried out on a population scale and the general concept is that a stressor does not have a similar effect depending on the genetic background of an individual or that a gene variant leads to a clinical phenotype only under certain environmental or behavioral conditions.

The study of epigenetic marks across the genome (epigenomics) provides critical data to inform both risk prediction and etiologic insight. Epigenetic marks can be modified by environmental factors, may be partially controlled by genetic variants, and regulate gene expression. There are increasing efforts internationally to decipher the interplay between genes, environment, epigenetics and diseases. In risk prediction, epigenetic marks can be used as biological markers of age or exposure to environmental factors. For example, epigenetic signatures were associated with active smoking [18] or prenatal exposure to maternal smoking [19]. Epigenetic mechanisms have been shown to mediate associations between genetic variants and immune-related diseases [20,21], thus bringing some insight into the underlying biological mechanisms. Epigenetic modifications can also provide a potential mechanism for $\mathrm{G} \times \mathrm{E}$ interactions, as observed for the response to stress exposure and the development of stress-related psychiatric disorders [22].

\section{The exposome-genome paradigm}

The question that arises when contemplating those impressive developments is how clinical medicine can benefit from such progress. In other words, can we include in a precision medicine perspective data reflecting exposures in addition to genetic information? At a large scale, integration of different levels of heterogeneous information can be achieved through a systems biology approach [23]. These could encompass both genetic data and components of the exposome, including multiomics data (metabolomics, epigenomics, transcriptomics...), therefore supporting a more comprehensive analysis of disease etiologies and of specific vulnerabilities. From a clinical point of view, it is important to see whether these concepts can have practical implications at the individual level. Clearly, the interactions between an exposure and the genetic background is relevant clinically as shown in several studies in the pharmacogenomics, nutrigenomics and toxicogenomics fields. Often, in those cases, genetic variants are integrated with a single exposure, i.e. diet, drug or a chemical toxicant. A challenge would be to have a larger integration of the different exposures with the aim to obtain a global and more realistic overview. Quantitative assessments of exposure are expected to be obtained through biomonitoring of chemicals, metabolomics and proteomics but also through data gathered from specific sensors when appropriate.

With recent and incoming accumulation of emerging high throughput data, e.g. genome sequencing and in the field of the exposome, a key direction of research will be to combine both exposure and genomics data. Several groups have started multi-scale modeling i.e. integrating multiomics data in a systems medicine approach [24]. Snyder calls his multiomics approach the integrative Personal Omics Profile (iPOP) which is powered by systems biology [25]. Hood also devised a systems medicine approach called the P4 medicine (Personalized, Preventive predictive and Participatory) and applied it recently using several omics and longitudinal follow up to assess correlation of various markers with well-being and health [26]. Therefore 
several projects aim at using high content data in addition to genomics in order to improve diagnostic and predictive capacities in medicine. In several cases significant achievements were attained, in particular concerning metabolic biomarkers that are either exogenous, microbial or endogenous [24,27].

To take advantage of these concepts in an individual setting, we propose a novel approach integrating the exposome and the genome (the exposome-genome paradigm). Genomic data will become more and more affordable, but the interpretation of human variations is not straightforward. Mapping those data with information on exposure will likely considerably improve the interpretation of the genomic data and their translation into specific recommendation. There is precedence for such approach. For example it is well known that alcohol consumption associated with certain variants of alcohol and aldehyde dehydrogenases is particularly toxic. The same holds true for the combination of certain drugs consumption and variants of xenobiotic metabolism enzymes. A comprehensive compilation of such associations will likely improve our knowledge on $\mathrm{G} \times \mathrm{E}$ interactions and thus improve our capacity to predict and prevent diseases (See Fig. 1).

\section{Conclusion}

New and emerging approaches in the fields of human genomics and exposomics, as well as their interactions together with the integration of large scale data from multiomics analyses may help to reveal/decipher potential biological mechanisms. Coupled with the increase of computational capacities, knowledge on disease etiologies, risk factors and response to treatment will increase. Based on this, each individual exposome and genome could be assessed and used as a tool for prevention. The following criteria could be taken into consideration:

- Since there have been successful applications of metabolomics, it seems reasonable to combine this technology with genomics as a first step. In fact, the metabolome is constituted of endogenous metabolites (and therefore a genetic influence), exogenous molecules such as drugs, nutrients and the most abundant contaminants as well as microbial substances. Therefore it integrates by itself a number of endogenous and exogenous influences.

- Few studies have included a comprehensive chemical contaminants profiling (beyond what traditional metabolomics could provide). We believe that such a profiling is now technically possible since human biomonitoring allowed the development of adequate technologies for the detection of trace amounts. However the cost of those technologies remains too high and precludes their use on a large scale.

- Data from medical history and from various sensors can also be considered since the exposome integrates a variety of environmental influences over time. Sensors detecting air pollutants could be valuable in specific cases, for examples asthmatic children or patients suffering from cardiovascular disease.

- With all these technologies, a close association of computational methods with clinical medicine and biology is obviously required for the patient benefits.

\section{Acknowledgements}

Authors received funds from Inserm (RB, KA, XC, FD, DG), Université Paris Descartes (RB, XC), Université Paris Diderot (KA, FD, DG), EU FP7 Heals (RB, XC), H2020 HBM4EU (RB, XC, KA).

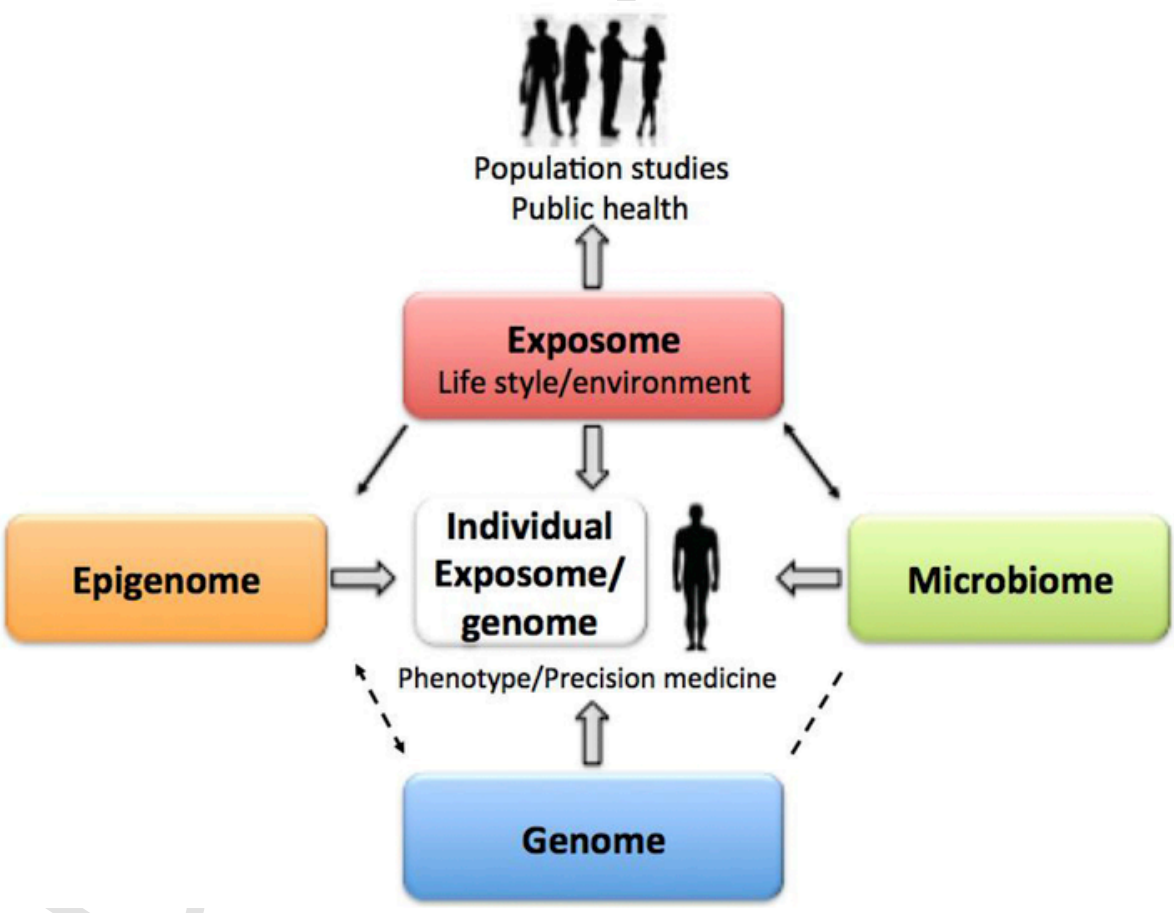

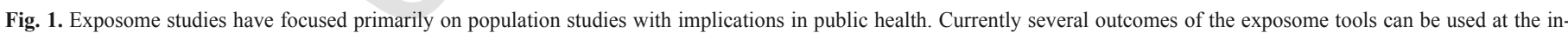

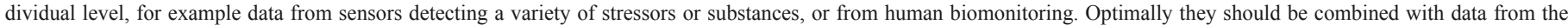

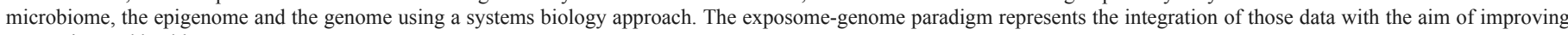
prevention and health. 


\section{References}

[1] U.E. Bauer, P.A. Briss, R.A. Goodman, B.A. Bowman, Prevention of chronic disease in the 21st century: elimination of the leading preventable causes of premature death and disability in the USA, Lancet Lond. Engl. 384 (2014) 45-52, https://doi.org/10.1016/S0140-6736(14)60648-6.

[2] D. Schwartz, F. Collins, Medicine. Environmental biology and human disease, Science 316 (2007) 695-696, https://doi.org/10.1126/science.1141331.

[3] C.P. Wild, Complementing the genome with an "exposome": the outstanding challenge of environmental exposure measurement in molecular epidemiology, Cancer Epidemiol. Biomark. Prev. Publ. Am. Assoc. Cancer Res. Cosponsored Am. Soc. Prev. Oncol. 14 (2005) 1847-1850, https://doi.org/10.1158/1055-9965. EPI-05-0456.

[4] T. Karjalainen, A. Hoeveler, R. Draghia-Akli, European Union research in support of environment and health: building scientific evidence base for policy, Environ. Int. 103 (2017) 51-60, https://doi.org/10.1016/j.envint.2017.03.014.

[5] M. Loh, D. Sarigiannis, A. Gotti, S. Karakitsios, A. Pronk, E. Kuijpers, I. Annesi-Maesano, N. Baiz, J. Madureira, E. Oliveira Fernandes, M. Jerrett, J.W. Cherrie, How sensors might help define the external exposome, Int. J. Environ. Res. Publ. Health 14 (2017) https://doi.org/10.3390/ijerph14040434.

[6] K.K. Dennis, S.S. Auerbach, D.M. Balshaw, Y. Cui, M.D. Fallin, M.T. Smith, A. Spira, S. Sumner, G.W. Miller, The importance of the biological impact of exposure to the concept of the exposome, Environ. Health Perspect. 124 (2016) 1504-1510, https://doi.org/10.1289/EHP140.

[7] G. Rook, F. Bäckhed, B.R. Levin, M.J. McFall-Ngai, A.R. McLean, Evolution, human-microbe interactions, and life history plasticity, Lancet Lond. Engl. 390 (2017) 521-530, https://doi.org/10.1016/S0140-6736(17)30566-4.

[8] E. Holmes, R.L. Loo, J. Stamler, M. Bictash, I.K.S. Yap, Q. Chan, T. Ebbels, M De Iorio, I.J. Brown, K.A. Veselkov, M.L. Daviglus, H. Kesteloot, H. Ueshima, L. Zhao, J.K. Nicholson, P. Elliott, Human metabolic phenotype diversity and its association with diet and blood pressure, Nature 453 (2008) 396-400, https://doi. org/10.1038/nature06882.

[9] P. Elliott, J.M. Posma, Q. Chan, I. Garcia-Perez, A. Wijeyesekera, M. Bictash, T.M.D. Ebbels, H. Ueshima, L. Zhao, L. van Horn, M. Daviglus, J. Stamler, E. Holmes, J.K. Nicholson, Urinary metabolic signatures of human adiposity, Sci. Transl. Med. 7 (2015) https://doi.org/10.1126/scitranslmed.aaa5680, 285 ra62.

[10] M.-E. Dumas, A.R. Rothwell, L. Hoyles, T. Aranias, J. Chilloux, S. Calderari, E.M. Noll, N. Péan, C.L. Boulangé, C. Blancher, R.H. Barton, Q. Gu, J.F. Fearnside, C. Deshayes, C. Hue, J. Scott, J.K. Nicholson, D. Gauguier, Microbial-host Co-metabolites are prodromal markers predicting phenotypic heterogeneity in behavior, obesity, and impaired glucose tolerance, Cell Rep. 20 (2017) 136-148, https://doi.org/10.1016/j.celrep.2017.06.039.

[11] M. Venkatesh, S. Mukherjee, H. Wang, H. Li, K. Sun, A.P. Benechet, Z. Qiu, L. Maher, M.R. Redinbo, R.S. Phillips, J.C. Fleet, S. Kortagere, P. Mukherjee, A. Fasano, J. Le Ven, J.K. Nicholson, M.E. Dumas, K.M. Khanna, S. Mani, Symbiotic bacterial metabolites regulate gastrointestinal barrier function via the xenobiotic sensor PXR and Toll-like receptor 4, Immunity 41 (2014) 296-310, https: //doi.org/10.1016/j.immuni.2014.06.014.

[12] A. Trompette, E.S. Gollwitzer, K. Yadava, A.K. Sichelstiel, N. Sprenger, C. Ngom-Bru, C. Blanchard, T. Junt, L.P. Nicod, N.L. Harris, B.J. Marsland, Gu microbiota metabolism of dietary fiber influences allergic airway disease and hematopoiesis, Nat. Med. 20 (2014) 159-166, https://doi.org/10.1038/nm.3444.

[13] M.J. Khoury, S. Galea, Will precision medicine improve population health?, J. Am. Med. Assoc. 316 (2016) 1357-1358, https://doi.org/10.1001/jama.2016. 12260 .

[14] K. Beebe, A.D. Kennedy, Sharpening precision medicine by a thorough interrogation of metabolic individuality, Comput. Struct. Biotechnol. J. 14 (2016) 97-105, https://doi.org/10.1016/j.csbj.2016.01.001.

[15] M. Janin, E. Mylonas, V. Saada, J.-B. Micol, A. Renneville, C. Quivoron, S. Koscielny, L. Scourzic, S. Forget, C. Pautas, D. Caillot, C. Preudhomme, H. Dombret, C. Berthon, R. Barouki, D. Rabier, N. Auger, F. Griscelli, E. Chachaty, E. Leclercq, M.-H. Courtier, A. Bennaceur-Griscelli, E. Solary, O.A. Bernard, V.
Penard-Lacronique, C. Ottolenghi, S. de Botton, Serum 2-hydroxyglutarate production in IDH1 - and IDH2-mutated de novo acute myeloid leukemia: a study by the Acute Leukemia French Association group, J. Clin. Oncol. Off. J. Am. Soc. Clin. Oncol. 32 (2014) 297-305, https://doi.org/10.1200/JCO.2013.50.2047.

[16] C.J. Patel, J. Bhattacharya, A.J. Butte, An Environment-Wide Association Study (EWAS) on type 2 diabetes mellitus, PLoS One 5 (2010)e10746https://doi.org/ 10.1371/journal.pone.0010746.

[17] L.P. Zhao, W. Fan, G. Goodman, J. Radich, P. Martin, Deciphering genome environment wide interactions using exposed subjects only, Genet. Epidemiol. 39 (2015) 334-346, https://doi.org/10.1002/gepi.21890.

[18] R. Joehanes, A.C. Just, R.E. Marioni, L.C. Pilling, L.M. Reynolds, P.R. Mandaviya, W. Guan, T. Xu, C.E. Elks, S. Aslibekyan, H. Moreno-Macias, J.A Smith, J.A. Brody, R. Dhingra, P. Yousefi, J.S. Pankow, S. Kunze, S.H. Shah, A.F. McRae, K. Lohman, J. Sha, D.M. Absher, L. Ferrucci, W. Zhao, E.W. Demerath, J. Bressler, M.L. Grove, T. Huan, C. Liu, M.M. Mendelson, C. Yao, D.P. Kiel, A. Peters, R. Wang-Sattler, P.M. Visscher, N.R. Wray, J.M. Starr, J. Ding, C.J. Rodriguez, N.J. Wareham, M.R. Irvin, D. Zhi, M. Barrdahl, P. Vineis, S. Ambatipudi, A.G. Uitterlinden, A. Hofman, J. Schwartz, E. Colicino, L. Hou, P.S. Vokonas, D.G. Hernandez, A.B. Singleton, S. Bandinelli, S.T. Turner, E.B. Ware, A.K. Smith, T. Klengel, E.B. Binder, B.M. Psaty, K.D. Taylor, S.A. Gharib, B.R. Swenson, L. Liang, D.L. DeMeo, G.T. O'Connor, Z. Herceg, K.J. Ressler, K.N. Conneely, N. Sotoodehnia, S.L.R. Kardia, D. Melzer, A.A. Baccarelli, J.B.J. van Meurs, I. Romieu, D.K. Arnett, K.K. Ong, Y. Liu, M. Waldenberger, I.J. Deary, M. Fornage, D. Levy, S.J. London, Epigenetic signatures of cigarette smoking, Circ. Cardiovasc. Genet. 9 (2016) 436-447, https://doi.org/ 10.1161/CIRCGENETICS.116.001506.

[19] S.E. Reese, S. Zhao, M.C. Wu, B.R. Joubert, C.L. Parr, S.E. Håberg, P.M. Ueland, R.M. Nilsen, Ø. Midttun, S.E. Vollset, S.D. Peddada, W. Nystad, S.J. London, DNA methylation score as a biomarker in newborns for sustained maternal smoking during pregnancy, Environ. Health Perspect. 125 (2017) 760-766, https://doi.org/10.1289/EHP333.

[20] Y. Liu, M.J. Aryee, L. Padyukov, M.D. Fallin, E. Hesselberg, A. Runarsson, L. Reinius, N. Acevedo, M. Taub, M. Ronninger, K. Shchetynsky, A. Scheynius, J. Kere, L. Alfredsson, L. Klareskog, T.J. Ekström, A.P. Feinberg,

Epigenome-wide association data implicate DNA methylation as an intermediary of genetic risk in rheumatoid arthritis, Nat. Biotechnol. 31 (2013) 142-147, https://doi.org/10.1038/nbt.2487.

[21] C. Sarnowski, C. Laprise, G. Malerba, M.F. Moffatt, M.-H. Dizier, A. Morin, Q.B. Vincent, K. Rohde, J. Esparza-Gordillo, P. Margaritte-Jeannin, L. Liang, Y.-A. Lee, J. Bousquet, V. Siroux, P.F. Pignatti, W.O. Cookson, M. Lathrop, T. Pastinen, F. Demenais, E. Bouzigon, DNA methylation within melatonin receptor $1 \mathrm{~A}$ (MTNR1A) mediates paternally transmitted genetic variant effect on asthma plus rhinitis, J. Allergy Clin. Immunol. 138 (2016) 748-753, https://doi. org/10.1016/j.jaci.2015.12.1341

[22] T. Klengel, E.B. Binder, Epigenetics of stress-related psychiatric disorders and gene X environment interactions, Neuron 86 (2015) 1343-1357, https://doi.org 10.1016/j.neuron.2015.05.036.

[23] K. Audouze, S. Brunak, P. Grandjean, A computational approach to chemical etiologies of diabetes, Sci. Rep. 3 (2013) 2712, https://doi.org/10.1038/ srep02712.

[24] D.S. Wishart, Emerging applications of metabolomics in drug discovery and precision medicine, Nat. Rev. Drug Discov. 15 (2016) 473-484, https://doi.org/10. 1038/nrd.2016.32.

[25] R. Chen, M. Snyder, Promise of personalized omics to precision medicine, Wiley Interdiscip. Rev. Syst. Biol. Med. 5 (2013) 73-82, https://doi.org/10.1002/ wsbm.1198.

[26] N.D. Price, A.T. Magis, J.C. Earls, G. Glusman, R. Levy, C. Lausted, D.T. McDonald, U. Kusebauch, C.L. Moss, Y. Zhou, S. Qin, R.L. Moritz, K. Brogaard, G.S. Omenn, J.C. Lovejoy, L. Hood, A wellness study of 108 individuals using personal, dense, dynamic data clouds, Nat. Biotechnol. 35 (2017) 747-756, https://doi.org/10.1038/nbt.3870.

[27] J.K. Nicholson, I.D. Wilson, J.C. Lindon, Pharmacometabonomics as an effector for personalized medicine, Pharmacogenomics 12 (2011) 103-111, https://doi. org/10.2217/pgs.10.157. 